\title{
Kecerdasan Emosional, Komunikasi Interpersonal, Kerja Tim dan Motivasi Mahasiswa Pendidikan Profesi Ners dalam Implementasi Inter Professional Education Di Rumah Sakit USU
}

\author{
Rika Endah Nurhidayah ${ }^{1}$, Hasmela Revi ${ }^{2}$ \\ Universitas Sumatera Utara, Medan, Indonesia ${ }^{1}$ \\ Rumah Sakit Universitas Sumatera Utara \\ Corresponding Authors: rika_endah@usu.ac.id
}

\begin{abstract}
ABSTRAK
Rumah Sakit Universitas Sumatera Utara adalah tempat menyelenggarakan pelayanan kesehatan, penelitian dan pendidikan yang memprioritaskan program pembelajaran bagi semua profesi baik kesehatan maupun non kesehatan yang ada di USU. Lima fakultas kesehatan yang melaksanakan pembelajaran di RS USU yaitu kedokteran, keperawatan, kesehatan masyarakat, psikologi, dan farmasi. IPE sangat dibutuhkan, namun banyak kendala untuk mengimplementasikannya. Berdasarkan hasil penelitian, beberapa faktor yang diasumsikan berkontribusi terhadap pelaksanaan IPE yaitu kecerdasan emosional, komunikasi interpersonal, kerja tim Inter Profesional Education (IPE) dan motivasi. Penelitian ini bertujuan untuk mengidentifikasi kecerdasan emosional, komunikasi interpersonal, kerja tim IPE dan motivasi mahasiswa program pendidikan profesi Ners di RSU USU. Sampelnya sebanyak 63 orang yang dipilih secara acak sederhana dari jumlah populasi 75 orang. Data dikumpulkan dengan cara menyebarkan angket. Hasil penelitian menunjukkan bahwa kecenderungan untuk semua variabel berada pada kategori baik, namun nilai ini masih berdasarkan asumsi dari profesi Ners, oleh kerena itu perlu diteliti kecenderungan semua variabel menurut profesi lainnya.
\end{abstract}

Kata Kunci: kecerdasan emosional, komunikasi, kerja tim, motivasi dan IPE

\section{PENDAHULUAN}

Rumah Sakit Universitas Sumatera Utara (RS USU) merupakan Rumah Sakit Perguruan Tinggi Negeri (RS PTN). RS PTN menyelenggarakan pendidikan, penelitian dan pelayanan secara terpadu, dalam bidang pendidikan profesi kedokteran, pendidikan kedokteran berkelanjutan, dan pendidikan tenaga kesehatan lainnya (UU No. 44 Tahun 2009). RS USU sebagai RS PTN menjadi wahana pendidikan Tenaga Kesehatan dan Non Tenaga Kesehatan. Terdapat lima fakultas yang ada di USU melaksanakan pendidikan di RS USU yaitu kedokteran, keperawatan, kesehatan masyarakat, psikologi, dan farmasi.

Tahun 2018 RS USU mencoba implementasi IPE (Inter Professional Education) yang melibatkan mahasiswa yang berasal dari lima fakultas kesehatan di USU pada saat melaksanakan praktik di RS USU. Gilbert (2010) mendefinisikan IPE dengan dua atau lebih profesi yang belajar dengan, dari, dan tentang sesuatu, satu sama lain untuk meningkatkan kolaborasi dan kualitas perawatan. Thistlethwaite, (2012) menyatakan bahwa IPE dapat diterapkan pada tatanan pendidikan maupun lingkungan kerja. 
Kerjasama antar profesi di lingkungan kerja dikenal dengan istilah Inter Profesional Colaboration (IPC). Rebecca, (2014) menyatakan bahwa tim interprofesional terdiri dari berbagai profesi kesehatan yang berbeda yang memiliki pengetahuan khusus, keterampilan, dan kemampuan. Jadi IPE dan IPC memang melibatkan lebih dari satu profesi yang berbeda

Penelitian Sulistiyowati, Kristina dan Santoso (2017) menyatakan bahwa terdapat peningkatan hubungan interpersonal antara perawat dan dokter pada kelompok yang diberikan pelatihan Bedside Interprofesional Round (BIR). Pelaksanaan BIR membutuhkan komunikasi, koordinasi dan adanya dukungan dari pimpinan secara komprehensif. Hal ini sejalan dengan penelitian Kusumaningrum dan Anggorowati (2018) yang menyatakan perlunya upaya pengembangan komunikasi antar profesi untuk mempersiapkan calon perawat agar mampu berkomunikasi dalam sebuah tim.

Hasil penelitian yang agak berbeda dari Hakiman, Dewi, Sayusman dan Wahyudi (2016) menyatakan bahwa pemahaman mahasiswa tentang profesi tenaga kesehatan lain sudah baik namun kerjasama profesional dalam tim masih dipersepsikan belum cukup memadai. Artinya masih perlu ditingkatkan lagi. Sundari dan Sembodo (2013) menemukan bahwa dalam pelaksanaan IPE pemahaman terhadap profesi lain memiliki rerata paling rendah karena kurangnya interaksi dan komunikasi antar profesi. Wijoyo dan Hananto (2017) menyatakan bahwa pembiasaan IPC bisa dilakukan dengan pendekatan IPE dilahan pendidikan. Kendala IPC adalah komunikasi dan kolaborasi sehingga dalam proses menuju IPC yang baik perlu IPE yang baik pula di lahan akademik. ketiga penelitian tentang IPE dan IPC diatas menyimpulkan bahwa komunikasi interpersonal memberikan kontribusi bermakna dalam kerjasama tim. Komunikasi dan kerjasama tim yang baik akan

Suhartini dan Anisa, (2017) melakukan penelitian yang berhubungan dengan kecerdasan emosional perawat, hasilnya menyatakan bahwa kecerdasan emosional berpengaruh positif dan signifikan terhadap kinerja perawat. Sebagai tim yang multi profesi, kemampuan mengelola emosi, komunikasi interpersonal yang baik, kefektifan tim dapat mempengaruhi kinerja.

Pelaksanann IPE di Indonesia baru tahap awal sehingga membutuhkan kerjasama dari berbagai pihak. Selain itu adanya isu ego profesi dimana sebuah profesi lebih penting dan memiliki derajat dan hak yang lebih superior dibandingkan profesi lain yang kenyataannya sampai sekarang sebagian masih bertahan dengan pola pikir tersebut. Kerjasama tim sangat dibutuhkan dalam hal ini. Hasil penelitian Yusuf (2015) pada mahasiswa dan dosen di FIK UIN Alauddin Makasar menemukan bahwa mayoritas dosen memiliki persepsi baik terhadap IPE begitu juga dengan mayoritas mahasiswa. Motivasi dibutuhkan untuk meningkatkan kinerja karyawan. Andriansyah, (2017) menyatakan motivasi memiliki pengaruh secara signifikan positif terhadap kinerja karyawan.

Berdasarkan beberapa penelitian yang telah dipaparkan di atas maka peneliti 
memfokuskan penelitian kepada beberapa faktor yang dianggap berkaitan dengan kegiatan Inter Profesional Education maupun Inter Profesional Colaboration. Namun peneliti mempersempit lingkup penelitian, yaitu penelitian ini hanya difokuskan menidentifikasi faktor kecerdasan emosional, komunikasi interpersonal, kerja tim dan motivasi pada mahasiswa pendidikan profesi Ners di Rumah Sakit Universitas Sumatera Utara.

\section{METODE PENELITIAN}

Desain penelitian yang pilih dalam penelitian ini adalah deskriptif yang bertujuan untuk mengidentifikasi kecerdasan emosional, komunikasi interpersonal, kerja tim inter profesional education (IPE) dan motivasi mahasiswa pendidikan profesi Ners di Rumah Sakit Universitas Sumatera Utara. Populasinya adalah seluruh mahasiswa program pendidikan profesi Ners yang sedang praktik di RS USU, jumlahnya sebanyak 75 orang. Penentuan jumlah sampel dapat dihitung dengan menggunakan rumus Slovin pada tingkat kepercayaan 95\%, didapatkan sampel sebanyak 63 orang. Teknik pengambilan sampel dengan simple random sampling (acak sederhana).

Penelitian ini dilaksanakan di lingkungan ruang rawat inap Rumah Sakit Universitas Sumatera Utara. Pengambilan data dilapangan kurang lebih selama satu bulan. Penelitian dilakukan setelah peneliti lulus uji etik dari Komisi Etik Penelitian Kesehatan Fakultas Keperawatan USU dan kemudian mendapat persetujuan dari RS USU dengan mempertimbangkan prinsip-prinsip etik meliputi (1) Informed Concent (Lembar Persetujuan Responden); (2) Anonimity (Kerahasiaan Identitas); dan (3) Confidentiality (Kerahasiaan Informasi).

Instrumen penelitian berupa kuesioner. Kuesioner terdiri dari empat paket sesuai dengan jumlah variabel penelitian. Kuesioner dikembangkan sendiri oleh peneliti beradasarkan teori pendukung. Setaip kuesioner disusun dengan mengkombinasikan unsur favourable dan non favourable. Soal dikembangkan sendiri maka disebelum digunakan terlebih dahulu dilakukan uji validitas konten dan reliabilitas. Setiap variabel memiliki 30 soal, dengan model penilaian skala Likert. Nilai terendah $=1$ dan nilai tertinggi $=5$, sehingga didapatkan skor ideal tertinggi $=150$ dan skor ideal terendah $=30$.

Uji validitas dan reliabilitas telah dilakukan. Uji validitas isi (content validity), dilakukan ahli yang terkait dengan bidang tersebut. Uji reliabilitas dengan rumus Cronbach alfa, dilakukan kepada 30 mahasiswa program pendidikan profesi di RS USU, dan didapatkan nilai reliabilitas keefektifan tim $\alpha=0,886$, komunikasi interpersonal $\alpha=0,672$, kecerdasan emosional $\alpha=0,899$, dan motivasi $\alpha=0,887$.

Data dikumpulkan dengan cara menyebarkan kuesioner kepada mahasiswa program pendidikan profesi Ners yang terpilih menjadi sampel penelitian. Pembagian kuesioner dilakukan bertahap mengikuti siklus mahasiswa di klinik. Selama pengisian mereka didampingi seandainya mengalami kesulitan atau 
membutuhkan penjelasan tambahan. Kuesioner dikumpulkan kembali pada hari yang sama untuk menghindari hilang atau rusak sehingga dapat menggangu proses penelitian.

Analisa dilakukan secara univariat. Analisa univariat merupakan analisa yang bertujuan untuk menjelaskan dan membuat deskripsi mengenai karakteristik setiap variabel dalam penelitian.

\section{HASIL PENELITIAN DAN PEMBAHASAN}

Deskripsi data penelitian menyajikan tentang skor rata-rata, skor minimun, skor maksimum, range, modus, median, dan simpangan baku. Untuk mempermudah dalam memahami data hasil penelitian, maka data juga ditampilkan dalam bentuk distribusi frekuensi dan diagram histogram. Ringkasan hasil perhitungan analisis deskriptif ditampilkan pada Tabel 1 berikut.

\section{Tabel 1. Ringkasan Hasil Perhitungan Statistik Deskriptif}

\begin{tabular}{llcccc}
\hline \multirow{2}{*}{ No } & \multirow{2}{*}{ Statistik } & \multicolumn{4}{c}{ Data Variabel } \\
\cline { 3 - 6 } & & $\mathbf{X}_{\mathbf{1}}$ & $\mathbf{X}_{\mathbf{2}}$ & $\mathbf{X}_{\mathbf{3}}$ & $\mathbf{X}_{\mathbf{4}}$ \\
\hline 1. & Skor Tertinggi Ideal & 150 & 150 & 150 & 150 \\
\hline 2. & Skor Tertinggi & 141 & 128 & 140 & 134 \\
\hline 3. & Skor Terendah Ideal & 30 & 30 & 30 & 30 \\
\hline 4. & Skor Terendah & 112 & 95 & 98 & 94 \\
\hline 5. & Range & 29 & 33 & 42 & 40 \\
\hline 6. & Paling sering muncul & 116 & 108 & 113 & 112 \\
\hline 7. & Nilai Tengah & 121 & 110 & 116 & 112 \\
\hline 8. & Rata-rata & 142,48 & 135,15 & 184,41 & 122,23 \\
\hline 9. & Rata-rata Ideal & 90 & 90 & 90 & 90 \\
\hline 10. & Simpangan Baku & 7,39 & 7,34 & 8,80 & 8,76 \\
\hline 11. & Simpangan Baku Ideal & 20 & 20 & 20 & 20 \\
\hline
\end{tabular}

Keterangan $\mathbf{X}_{\mathbf{1}}=$ keefektifan tim

$\mathbf{X}_{2}=$ komunikasi interpersonal

$\mathbf{X}_{3}=$ kecerdasan emosional

$\mathbf{X}_{4}=$ motivasi

Berdasarkan tabel 1, terlihat bahwa skor tertinggi dari setiap variabel mendekati skor tertinggi ideal, sedangkan nilai terendahnya jauh di atas skor nilai terendah ideal. Hal ini sejalan dengan nilai atau skor rata-rata untuk semua variabel berada jauh di atas rata-rata idel. Artinya gambaran tentang keefektifan tim, komunikasi interpersonal, kecerdasan emosional, dan motivasi mahasiswa keperawatan sudah baik. Nilai simpangan baku dari setiap variabel juga sangat 
rendah artinya mahasiswa program pendidikan profesi Ners ini memiliki pemahaman yang hampir sama atau homogen untuk keefektifan tim, komunikasi interpersonal, kecerdasan emosional, dan motivasi dalam mengimpelentasikan IPE. Hasil ini didukung dengan data skor terendah dan tertinggi yang tidak terlalu jauh berbeda.

Hasil penelitian kemudian dikategorikan ke dalam empat kelompok, yaitu tinggi, sedang, rendah dan kurang. Gambaran kecenderungan hasil pengukuran untuk semua variabel akan digambarkan pada tabel 2.

Tabel 2. Tingkat Kecenderungan

\begin{tabular}{|c|c|c|c|c|c|c|}
\hline No & $\begin{array}{c}\text { Rentang } \\
\text { Nilai }\end{array}$ & $\begin{array}{c}\text { Frekuensi } \\
\text { Keefektifan } \\
\text { Tim }\end{array}$ & $\begin{array}{c}\text { Frekuensi } \\
\text { Komunikasi } \\
\text { Interpersonal }\end{array}$ & $\begin{array}{c}\text { Frekuensi } \\
\text { Kecerdasan } \\
\text { Emosional }\end{array}$ & $\begin{array}{c}\text { Frekuensi } \\
\text { Motivasi }\end{array}$ & Kategori \\
\hline 1 & $\geq 120$ & $\begin{array}{c}33 \\
(52,4 \%) \\
\end{array}$ & $\begin{array}{c}6 \\
(9,5 \%) \\
\end{array}$ & $\begin{array}{c}18 \\
(28,6 \%) \\
\end{array}$ & $\begin{array}{c}13 \\
(20,6 \%) \\
\end{array}$ & Tinggi \\
\hline 2 & $\begin{array}{c}90 \mathrm{~s} / \mathrm{d} \\
120\end{array}$ & $\begin{array}{c}30 \\
(47,6 \%)\end{array}$ & $\begin{array}{c}57 \\
(90,5 \%)\end{array}$ & $\begin{array}{c}45 \\
(71,4 \%)\end{array}$ & $\begin{array}{c}50 \\
(79,4 \%)\end{array}$ & Sedang \\
\hline 3 & $\begin{array}{c}60 \mathrm{~s} / \mathrm{d} \\
90\end{array}$ & $\begin{array}{c}0 \\
(0 \%)\end{array}$ & $\begin{array}{c}0 \\
(0 \%) \\
\end{array}$ & $\begin{array}{c}0 \\
(0 \%) \\
\end{array}$ & $\begin{array}{c}0 \\
(0 \%) \\
\end{array}$ & Rendah \\
\hline 4 & $\leq 60$ & $\begin{array}{c}0 \\
(0 \%)\end{array}$ & $\begin{array}{c}0 \\
(0 \%) \\
\end{array}$ & $\begin{array}{c}0 \\
(0 \%) \\
\end{array}$ & $\begin{array}{c}0 \\
(0 \%) \\
\end{array}$ & Kurang \\
\hline
\end{tabular}

Berdasarkan tabel $2 \mathrm{di}$ atas diperoleh tingkat kecenderungan skor data untuk semua variabel berada pada kategori tinggi dan sedang saja, artinya pemahaman mereka tentang keefektifan tim, komunikasi interpersonal, kecerdasan emosional, dan motivasi mahasiswa program pendidikan profesi Ners sudah baik. Barr, (2002); WHO, (2010) mengemukakan bahwa Interprofesional Education (IPE) adalah suatu proses kegiatan dimana sekelompok mahasiswa khususnya mahasiswa profesi kesehatan yang memiliki perbedaan latar belakang, nilai-nilai, dan kultur profesi yang berbeda melakukan kegiatan pembelajaran bersama pada kurun waktu tertentu dengan tujuan utama dapat berinteraksi, berkomunikasi dan berkolaborasi bersama dalam upaya-upaya peningkatan pelayanan kesehatan baik promotif, preventif, kuratif, dan rehabilitatif, serta jenis pelayanan kesehatan lainnya. Rebecca (2014) menambahkan bahwa tim interprofesional terdiri dari anggota dari profesi kesehatan yang berbeda yang memiliki pengetahuan khusus, keterampilan, dan kemampuan.

Penelitian Hakiman, Dewi dan Wahyudi, (2016) dengan metode penelitian analitik komparatif menggunakan kuesioner Interdisciplinary Education Perception Scale (IEPS) yang diterjemahkan, menemukan bahwa persepsi 98\% responden masuk ke dalam kategori baik. Komponen IPE untuk "Kebutuhan yang dirasakan untuk kerjasama profesional" memiliki persepsi baik yang lebih rendah dibandingkan dengan komponen "Kompetensi dan otonomi" dan "Persepsi kerjasama aktual". 
Penelitian yang sejalan dari Yusuf (2015) yang menunjukkan bahwa mayoritas mahasiswa FIK UIN Alauddin Makassar memiliki persepsi baik terhadap IPE dengan persentase $92,3 \%$.

Dua penelitian lain yang menggunakan kuesioner yang sama dari Wahyuni (2019) yang menunjukkan bahwa $72.0 \%$ mahasiswa berpersepsi baik terhadap komponen kompetensi dan otonomi, kebutuhan untuk bekerjasama, persepsi bekerjasama yang sesungguhnya, dan pemahaman terhadap profesi lain dan masih ada $28 \%$ mahasiswa masih memiliki persepsi sedang dengan semua komponen IPE. Penelitian Balqis (2018) senakin menguatkan bahwa sebagian besar mahasiswa berpersepsi positif terhadap komponen persepsi kompetensi dan otonomi, kebutuhan untuk bekerjasama, persepsi bekerjasama yang sesungguhnya dan pemahaman terhadap profesi lain, Namun terjadi perbedaan persepsi yang signifikan antara mahasiswa kedokteran umum, farmasi dan keperawatan terhadap komponen persepsi pemahaman terhadap profesi lain.

Berdasarkan empat paparan penelitian terkait dengan persepri implemtasi IPE, maka dapat disimpulkan bahwa kebanyakan sudah memberikan persepsi yang positif. Berdasarkan pendekatan kerjasama tim, dan capaian kualitas pelayanan memiliki outcome pendidikan yang jelas pada perguruan tinggi, maka pendekatan model pembelajaran ini sangat tepat untuk digunakan. Menurut CIHC (2009) menjelaskan hal yang sama bahwa tujuan implementasi IPE pada mahasiswa adalah terbangunnya kemampuan teamwork yang saling melengkapi antara satu profesi dengan profesi lainnya sehingga mereka mampu bekerja dengan profesional kesehatan lainnya.

CICH (2009) menyatakan bahwa model pembelajaran IPE pada proses pendidikan klinik/lapangan memiliki manfaat sebagai berikut:

1. Meningkatkan pengalaman praktek belajar klinik yang dapat meningkatkan pelayanan dan memberikan hasil yang positif dalam melayani klien.

2. Meningkatkan kemampuan kompetensi pengetahuan, sikap dan keterampilan yang memerlukan kerja tim secara kolaborasi.

3. Memberikan pengalaman belajar klinik/lapangan yang berbeda bagi peserta didik ketika mereka dapat melakukan kegiatan secara bersama dan bersinergi dalam ruang lingkup pelayanan kesehatan.

4. Mengembangan model praktek belajar klinik/lapangan yang dapat diimplementasikan secara fleksibel dan ditetapkan dalam berbagai setting pelayanan kesehatan. 


\section{KESIMPULAN}

Berdasarkan paparan di atas maka dapat disimpulkan bahwa pemahaman mahasiswa program pendidikan profesi Ners tentang keefektifan tim, komunikasi interpersonal, kecerdasan emosional, dan motivasi sudah baik dalam Interprofesional Education (IPE). IPE memang dibutuhkan dalam proses pembelajaran di klinik maupun komunitas. IPE yang dilaksanakan sejak program pendidikan akademik dapat memberikan dampak yang positif untuk pelaksanaan Interprofesional Colaboration (IPC). Sarannya adalah mengidentifikasi pemahaman profesi lain selama tentang Interprofesional Education (IPE), sehingga dapat menjadi masukan berarti untuk menyempurnakan implementasi IPE maupun IPC.

\section{UCAPAN TERIMA KASIH}

Ucapan terima kasih disampaikan kepada Lembaga Penelitian Universitas Sumatera Utara yang telah memberikan bantuan hibah TALENTA 2019 dengan kategori Penelitian Dasar untuk pelaksanaan penelitian ini.

\section{DAFTAR PUSTAKA}

Andriansyah, F. I. 2017. Pengaruh Beban Kerja, Stress Kerja dan Motivasi terhadap Kinerja Perawat Pada Rumah Sakit Jiwa Amino Gondohutomo Provinsi Jawa Tengah. Universitas Diponegoro: Skripsi

Balqis, N. (2018). Perbedaan Persepsi Mahasiswa Kesehatan terhadap Interprofessional Education (IPE). Universitas Muhammadiyah Surakarta. Skripsi

Bar, H. dan Low, H. 2011. Promoting Health and Wellbeing to Improve the Health and Social care of The Public by Advancing Inter Profesional Education. Principles of Inter Professional Education. https://www.caipe.org/resources/publications/barrlow-2011-principles-interprofessional-education

$\mathrm{CICH}$ (The Canadian Interprofessional Health Collaborative). (2009). A National Interprofessional Competency Framework: Draft for Discussion. Unpublish. https://www.cich.ca.

Gilbert, John. (2010). The Status of Interprofessional Education in Canada. Journal of Allied Health, suppl. Special Issue on Interprofessional Education and Care; Washington. Vol. 39, Iss. 3, P. 216-23. Diunduh 1 Oktober 2017.

Hakiman, A. P. A., Dewi, S.P., Sayusman, C., Wahyudi, K. Persepsi Mahasiswa Profesi Kesehatan Universitas Padjadjaran terhadap Interprofessionalism Education. Jurnal Ssitem Kesehatan. Volume 1 Nomor 4 Tahun 2016. Hal 206-213.S

Kusumaningrum, P., R. dan Anggorowati. Interprofessionalism Education Sebagai Upaya Membangun Kemampuan Perawat dalam Berkolaborasi dengan Tenaga Kesehatan Lain. Jurnal Kepemimpinan dan Manajemen Keperawatan. Vol 
1. No. Mei 2018. Hal 14-19.

Rebecca, Grainger. Confident, Credible, but Lonely-Outcomes Following Postgraduate Interprofessional Education in Rehabilitation. Journal of Research in Interprofessional Practice and Education. Vol. 4.2. 2014

Suhartini, E. dan Anisa, N. Pengaruh Kecerdasan Emosional dan Kecerdasan Emosional terhadap Kinerja Perawat Rumah Sakit Labuang Baji Makasar. Jurnal Manajemen Ide dan Inspirasi (MIND). Vol 4 No.1, Juni 2017. ISSN 2442 4951.

Sulistyowati, A. D., Kristina, T.N., Santoso, A. (2017). Efektivitas Penerapan Bedside Interprofessional Rounds (BIR) untuk Meningkatkan Hubungan Interpersonal Perawat Dan Dokter. Universitas Diponegoro: Skripsi.

Sundari S. dan Sembodo, A. (2013). Perbedaan Persepsi Mahasiswa Tahap Profesi di FKIK UMY tentang Interprofessional Education di Asri Medical Center Yogyakarta. Med Educ. FKIK UMY. Hal 1-8.

Thistlethwaite, J. (2012). Interprofessional Education: a Review of Context, Learning and The Research Agenda. Centre for Medical Education Research and Scholarship, School of Medicine, University of Queensland, Brisbane, Queensland, Australia.

UU No. 44 Tahun 2009 tentang Rumah Sakit.

WHO (World Health Organization). 2010. Framework for Action on Interprofessional Education and Coolaborative Practice. http://www.who.int/hrh/nursing_midwifery/en/. Diunduh 2 Juli 2015.

Wahyuni, Y. T. (2019). Gambaran Persepsi Mahasiswa Fakultas Ilmu Kesehatan. Terhadap Pelaksanaan Interprofessional Education (IPE) di Komunitas. Universitas Muhammadiyah Surakarta. Skripsi

Wijoyo, E. B., Hananto, S. Pengembangan Pasien Virtual untuk Peningkatan Pendekatan Inter-Professional Education (IPE) dalam Dunia Pendidikan Keperawatan di Indonesia. Jurnal Keperawatan Muhammadiyah 2 (1) 2017. Hal 175-184.

Yusuf, S. (2015). Pengembangan Model Interprofessional Education (IPE). Skripsi. Fakultas Ilmu Kesehatan UIN Alauddin Makassar, Skripsi 2015. 